\title{
Caffeine Habits among Medical Students in King Saud University
}

\author{
Yousif Al-turki ${ }^{1}$, Basel Alenazy ${ }^{2}$, Abdulrhman Algadheeb ${ }^{3}$, Mazi Alanazi ${ }^{4}$, Abdulsalam Almarzouqi ${ }^{5}$, \\ Abdulrahman Alanazi ${ }^{6}$, Abdulelah Alanazi ${ }^{7}$, Mohammed Alanazi ${ }^{8}$ \\ 1, 2, 3, 4, 5, 6, 7, ${ }^{8}$ College of Medicine, King Saud University, Riyadh, SaudiArabia
}

\begin{abstract}
Background: caffeinated beverages have been one of the most consumed drinks. Since it is a psychoactive substance, medical students used to consume it more than other students to overcome the stress they face due to studying. Objectives: estimation of the daily amount of caffeine consumption among medical students in college of medicine at KSU in Riyadh in 2012 and comparison the amount of caffeine consumption among medical students based on the source of caffeine. Method: A cross-sectional study design using a 26 questions self-administered questionnaire was distributed to 550 medical students (275 male and 275 female) at college of medicine, King Saud University, Riyadh, Saudi Arabia. Results: (97.5\%) of medical students are consuming caffeine while only (2.5\%) of them haven't used it. Low intake caffeine users represent the majority by (49.3\%). However, moderate and high caffeine intake users are (28\%) and (22.7\%) respectively. Caffeine was the most common used beverage among both male and female students. Conclusion: we found a very high percentage of caffeine consumers among medical students. However, their use is still in the safe side. In other hand, high intake users which represent the smallest percentage should try to minimize the daily caffeine use.
\end{abstract}

Keywords: caffeine, coffee, medical student, medicine, Riyadh

\section{Introduction}

Caffeine Habits among Medical Students in King Saud University

Caffeine (1, 3, 7-trimethylxanthine) is a natural alkaloid. Caffeine is found in common beverages (coffee, tea, and soft drinks), products containing cocoa or chocolate, and medications, including headache or pain remedies and overthe- counter stimulants [1]. Standard values for caffeine content in these foods and beverages have been established [2]

Caffeine is the most widely consumed psychoactive substance in the world [1].That is noticeable by the huge increase in numbers of coffee shops. People consume it mainly to be awake and active through the whole day in order to keep up with their works and activities.

The most recent large-scale published epidemiologic data on caffeine consumption in the United States was collected more than 10 years ago. Based on the Continuing Survey of Food Intake by individuals in 1994 to 1996 and in 1998, it is estimated that $87 \%$ of the population in the United States 2 years and older regularly consume caffeine with an average daily consumption of about $193 \mathrm{mg}$ [3]. Caffeine use tends to increase with age with the highest consumption observed among adults aged 35 to 64 years [3]. Caffeine consumption among adult consumers in the United States is estimated to be about $280 \mathrm{mg}$ with higher daily intake estimated for some European countries [4].

A survey on the potential intake of caffeine was carried out in Brazil in 1993. The average and median potential daily intake of caffeine in the studied population were, respectively, 2.74 and $1.85 \mathrm{mg} / \mathrm{kg}$ [5]. In another survey concerning caffeine levels in retail beverages in Portugal, daily caffeine intake was estimated to range from 4.7 to 200 $\mathrm{mg} /$ day [6].
In Australia, a survey of 4757 Australian was conducted to assess usual daily consumption of caffeine from all sources. The average caffeine consumption was $240 \mathrm{mg} /$ day [7]. However, only 3 percent of the population was true abstainers from caffeine.

One setting in which caffeine may be consumed more among college students. A study was conducted and showed the average college student reported consumption is about one cup (70 mg) of caffeine per day [8]. Also, a study has been conducted on college students in the United States of America. The results showed that $51 \%$ of participants reported drinking greater than one energy drink each month in an average month for the current semester, with significantly more female (53\%) than male (42\%) energy drink users reported and the most common reason to drink energy drinks was insufficient sleep, as indicated by $67 \%$ of energy drink users [9].

The study of Medicine is extensive, time-consuming and very stressful. In every five-years study period students are subjected to endless working hours, and exams add an extra stress quotient. In order to maintain a remarkable gradepoint- average (GPA) students often have to work beyond their mental threshold and physical strength. Therefore, medical students are one of the most susceptible and more prone to consume caffeine than others among college students. However, few studies have been conducted to find out caffeine habits among medical students as far as our search in the literature.

In aspect of the physiological effects of caffeine, a study was conducted to elicit an awareness of the neurophysiologic effects of caffeine through its biochemical pathways in the human body. In summary, the health benefits from caffeine are increased arousal and facilitating against stress in the human body. These benefits are important in maintaining safety and efficacy in the workplace and other environments. To derive an increase in arousal could lead to individuals 


\section{International Journal of Science and Research (IJSR) \\ ISSN (Online): 2319-7064 \\ Index Copernicus Value (2013): 6.14 | Impact Factor (2014): 5.611}

over consuming caffeine drinks, this over consumption could then bring about some of the disadvantages such as anxiety and panic attacks or cause individuals to hallucinate (when doses more than $300 \mathrm{mg}$ caffeine are ingested) [10].

\section{Methods}

\section{Study Design}

This is a cross sectional study design. It was conducted in college of medicine at King Saud University in Riyadh on the medical students. The subjects have been chosen under inclusion and exclusion criteria. Male and female medical students from all academic years (from $1^{\text {st }}$ to $5^{\text {th }}$ year) will be included in the study. However, other medical staff such as: interns, residents, physicians, technicians and nurses will be excluded.

\section{Study Population}

Sample size is 550 medical students (275 males and 275 females). A simple random sampling technique was applied using random number generator application.

\section{Data Collection}

Data was collected from the subjects using self-administered questionnaires which were distributed among them at their classes immediately after the first lecture during the period from January $26^{\text {th }}$ to February $12^{\text {th }}$ of 2013. The questionnaire is formed of 26 questions divided into 3 sections (demographic section, caffeine consumption habits section and awareness of caffeine effects section). Questions 1-3 are general demographic questions. Questions 4-12 are assessing the caffeine consumption habits of the subjects to know if they use caffeine or not, type of caffeinated beverages if used, size of the cup, numbers of drinks per day or week and the purpose of caffeine consumption. Question 13-26 explore awareness of the subjects about caffeine effects on different body systems.

\section{Statistical Analysis}

Data was coded by hand and entered in the computer by Microsoft Excel 2007. Then, SPSS (version18) was used for data analysis from February $16^{\text {th }}$ to March $6^{\text {th }}$ of 2013 and three members of the team were involved in this process.

\section{Results}

Total number of the participants in the study was 550 medical students (275 male and 275 female). 536 (97.5\%) of them are consuming caffeine and only 14 students $(2.5 \%)$ are not consumers. Out of the non-consumer individuals, 7 students $(50 \%)$ stated the reason for not consumption is that caffeine is harmful to the health, $(35.7 \%)$ because they hate the taste, $(7 \%)$ because it is expensive, and $(7 \%)$ for other reasons. Among the consumer students, mean of the amount of caffeine consumption is

$312.26 \mathrm{mg} / \mathrm{d}$. However, the mean among male is $(320.47$ $\mathrm{mg} /$ day) and (304.14 mg/day) among female (Table 1).

The consumers have been categorized into three categories: (1) low intake (1- $199 \mathrm{mg} / \mathrm{d})$ is 264 students (49.3\%), (2) moderate intake $(200-399 \mathrm{mg} / \mathrm{d})$ is 150 students $(28 \%)$, and (3) high intake (more than $400 \mathrm{mg} / \mathrm{d}$ ) is 122 students $(22.7 \%$ )
(Table 2).

The results showed that the main source of caffeine intake is coffee $(96.2 \%)$, then soft drinks $(73.5 \%)$, and then energy drinks (11.1\%). However, 398 students (74.25\%) are drinking both coffee and soft drinks. 115 students are drinking coffee only and 23 students are drinking soft drink only.

Arabic/black coffee is the most common consumed beverage type of coffee among male students. However, Caffe latte/ cappuccino is the most one consumed among female students.

Pepsi and Red bull are the most common used beverage type of soft drinks and energy drinks respectively among both male and female students.

As for the reasons for consumption of caffeine, (56.5\%) of them consume it in order to feel more alert, (46.4\%) to keep awake in the morning, (44.5\%) because of the taste, $(42.5 \%)$ to help in concentration while studying, $(33.6 \%)$ to be in a better mood, $(21.3 \%)$ to help in relaxing, $(19.5 \%)$ to combat headache, $(16.7 \%)$ to combat drowsiness, $(8.9 \%)$ to help in dealing with stress, $(6.5 \%)$ to help dealing with depression, and $(3.3 \%)$ think that it can help in control the body weight (Figure 1).

In aspect of the students' awareness of caffeine effects, the results showed that $(69.2 \%)$ of the medical students believe that caffeine increases arousal, $(36.2 \%)$ believe that caffeine decreases fatigue, $(71.6 \%)$ believe caffeine can cause restlessness, $(77.6 \%)$ believe caffeine can increase heart rate, $(59.3 \%)$ believe caffeine can increase blood pressure, $(61.7 \%)$ believe caffeine can cause anxiety, (69.4\%) believe caffeine consumption in high dose for long time can cause addiction, $(8.8 \%)$ believe caffeine consumption in high dose for long time can cause hallucination (Figure 2). As the results showed, there is no relationship between awareness of caffeine effects and the academic year.

Out of 536 consumer students, only $83(15.5 \%)$ tried to quit caffeine consumption but couldn't (Table 4, Figure 12). However, (29\%) find it is hard to concentrate, $(28 \%)$ feel urge to consume caffeine, (16\%) feel more irritable, $(14 \%)$ feel nervous, and (13\%) feel anxious when they tried to quit caffeine.

\section{Discussion}

536 medical students $(97.5 \%)$ are considered as caffeine consumers and only 14 students $(2.5 \%)$ are abstainers from caffeine. A survey has been conducted in an American medical college and showed only (17.6\%) are consuming caffeine [15]

However, non-consumption was mainly due to the harm of caffeine on health. That reflects the high level of awareness among medical students.

The mean milligram of caffeine consumed per day in the present study was 312.26 , which is estimated based on the information about caffeine content in beverages provided by 


\section{International Journal of Science and Research (IJSR) \\ ISSN (Online): 2319-7064}

Index Copernicus Value (2013): 6.14 | Impact Factor (2014): 5.611

Centre for Science in the Public interest. This is much lesser than $849.86 \mathrm{mg} / \mathrm{d}$ which is reported by University of Kentucky [16]. However, it is higher than $240 \mathrm{mg}$ /day which is reported by a study in Australia [7].

U.S. Food and Drug Administration (FDA) and American Medical Association (AMA) classify consumption into (1) low intake which is up to $199 \mathrm{mg} / \mathrm{d}$, (2) moderate intake which is ranged from 200 to $399 \mathrm{mg} / \mathrm{d}$ and this is recognized as safe, (3) high intake which is defined as more than 400 $\mathrm{mg} / \mathrm{d}$. In the present study, it is found that the majority of students are classified as low intake users by (49.3\%). However, only $(22.7 \%)$ are defined as high intake users which is higher than those in Japanese Medical School $(15.2 \%)$ [17].

Coffee is on the top of caffeine sources. The same result has been found in an American study [18]. However, the results in this study showed that about (75\%) of the consumers drink both coffee and soft drinks. So, it is rarely to find a medical student drinks only a single caffeinated beverage.

It is found that black/Arabic coffee, Pepsi, and Red bull are the preferable type of coffee, soft drinks, and energy drinks respectively among male students. However, female prefer the same types except in that Caffe latte/cappuccino is preferred in aspect of coffee. That is because of female like sweet beverage more than male. Furthermore, about (57.9\%) said they consume more caffeine while studying for exam. It is explained by the stress they want to overcome during exams period [19].

Being more alert $(56.5 \%)$ was the most common reason for caffeine consumption while keep awake in morning (76\%) is the first reason for consumption in another study in America [16].

A study was conducted to explain the neurophysiologic impact of caffeine [10]

It showed that the benefits of caffeine are increase arousal and decrease fatigue. However, the disadvantages are many such as: restlessness, increase heart rate, increase blood pressure, anxiety, addiction for long time of high dose, and hallucination for long time of high dose.

In this study, the results showed that majority of the students are aware of the effects. The levels of awareness among those benefits and disadvantages are very close to each other. However, the highest percentage $(77.6 \%)$ represents awareness of the effect on the cardiac system by increase heart rate. However, only $(8.8 \%)$ believed that caffeine consumption in high dose for long time can lead to hallucination while the study has proved that effect [10].

Also, it is found in this study that $(15.5 \%)$ of the consumers tried to quit consumption but they couldn't and developed some symptoms like difficulty in concentration, feeling nervous, anxious, irritable, and urge to consume caffeine. These results support those reported by Silverman [20] and Strain [21]

\section{Conclusion}

We found a very high percentage of caffeine consumers among medical students. However, their use is still in the safe side. In other hand, high intake users which represent the smallest percentage should try to minimize the daily caffeine use.

\section{Future Scope}

Also, we recommend medical students in other colleges to conduct such study to know the extent of caffeine use among all Saudi medical students.

\section{References}

[1] Kendler KS, Prescott CA. Caffeine intake, tolerance and withdrawal in women: A population-based twin study. American Journal of Psychiatry 1999; 156: 223-228.

[2] Barone JJ, Roberts HR. Caffeine consumption. Food Chemistry and Toxicology 1996; 34: 119-129.

[3] Frary CD, Johnson RK, Wang MQ. Food sources and intakes of caffeine in the diets of persons in the United States. I Am Diet Assoc. 2005; 105: 110-113.

[4] Barone JJ, Roberts HR. Caffeine Consumption. Food Chemo Toxicol. 1996; 34: 119-129.

[5] Camargo MCR, Toledo MCF, Farah HG. Caffeine daily intake from dietary sources in Brazil. Food Additives and Contaminants 1999; 16: 79-87.

[6] Pena A, Lino C, Silveira MIN. Survey of caffeine levels in retail beverages in Portugal. Food Additives and Contaminants 2005; 22: 91-96.

[7] Shirlow MJ. Patterns of caffeine consumption. Human nutrition Applied nutrition. 1983 Aug;37(4):307-13.

[8] Loke, W. H. Caffeine consumption by college undergraduates. Psychology: A Journal of Human Behavior 1988; 25. 8-11.

[9] Malinauskas BM, Aeby VG, Overton RF, CarpenterAeby T, Barber-Heidal

[10]K. A survey of energy drink consumption patterns among college students. Nutrition journal. 2007;6:35.

[11] Persad LA. Energy drinks and the neurophysiological impact of caffeine. Frontiers in neuroscience. 2011;5:116.

[12]Riksen NP, Rongen GA, Smits P. Acute and long-term cardiovascular effects of coffee: implications for coronary heart disease. Pharmacology \& therapeutics. [Research Support, Non-U.S. Gov't Review]. 2009 Feb;121(2):185-91.

[13] Chou T. Wake up and smell the coffee. Caffeine, coffee, and the medical consequences. The Western journal of medicine. [Review]. 1992 Nov;157(5):544-53.

[14] Smith A. Effects of caffeine on human behavior. Food and chemical toxicology : an international journal published for the British Industrial Biological Research Association. [Review]. 2002 Sep;40(9):1243-55.

[15] Nardi AE, Lopes FL, Valenca AM, Freire RC, Veras $\mathrm{AB}$, de-Melo-Neto VL, et al. Caffeine challenge test in panic disorder and depression with panic attacks. Comprehensive psychiatry. [Randomized Controlled Trial Research Support, Non-U.S. Gov't]. 2007 MayJun; 48(3):257-63. 


\section{International Journal of Science and Research (IJSR) \\ ISSN (Online): 2319-7064}

Index Copernicus Value (2013): 6.14 | Impact Factor (2014): 5.611

[16] Grafton WD, Bairnsfather LE. Use of psychoactive substances by medical students: a survey. The Journal of the Louisiana State Medical Society : official organ of the Louisiana State Medical Society. 1991 Jun;143(6):27-9.

[17] Gary Eugene McIlvain. CAFFEINE CONSUMPTION PATTERNS AND BELIEFS OF COLLEGE FRESHMEN. University of Kentucky Doctoral Dissertation. 2008; 5: 28-30.

[18]Y, Yasuda N, Fujimura T, Ohara H. Caffeine consumption among medical students. Arukoru kenkyu to yakubutsu izon = Japanese journal of alcohol studies \& drug dependence. 1990 Dec; 25(6):475-85.

[19] Gilbert RM. Caffeine consumption. Progress in clinical and biological research. 1984;158:185-213.

[20] Khan MS, Mahmood S, Badshah A, Ali SU, Jamal Y. Prevalence of depression, anxiety and their associated factors among medical students in Karachi, Pakistan. J Pak Med Assoc 2006; 56:583-6.

[21] Silverman K, Mumford GK, Griffiths RR. Enhancing caffeine reinforcement by behavioral requirements following drug ingestion. Psychopharmacology 1994; 114: 424-432.

[22] Strain EC, Mumford GK, Silverman K, Griffiths RR. Caffeine dependence syndrome. JAMA. 1994; 272: 1043- 1048 
International Journal of Science and Research (IJSR)

ISSN (Online): 2319-7064

Index Copernicus Value (2013): 6.14 | Impact Factor (2014): 5.611

Table 1: Mean and Standard Deviation of Amount of Consumed Caffeine/ day

Amount of consumed caffeine/ day

\begin{tabular}{|c|c|c|}
\hline Gender & Mean & Std. Deviation \\
\hline Male & 320.47 & 438.666 \\
\hline Female & 304.14 & 365.579 \\
\hline
\end{tabular}

Table 2: Classification of Caffeine Consumers

\begin{tabular}{|c|c|c|}
\hline Category & Frequency & Percent \\
\hline Low intake & 264 & 49.3 \\
\hline Moderate intake & 150 & 28 \\
\hline High intake & 122 & 22.7 \\
\hline Total & 536 & 100.0 \\
\hline
\end{tabular}

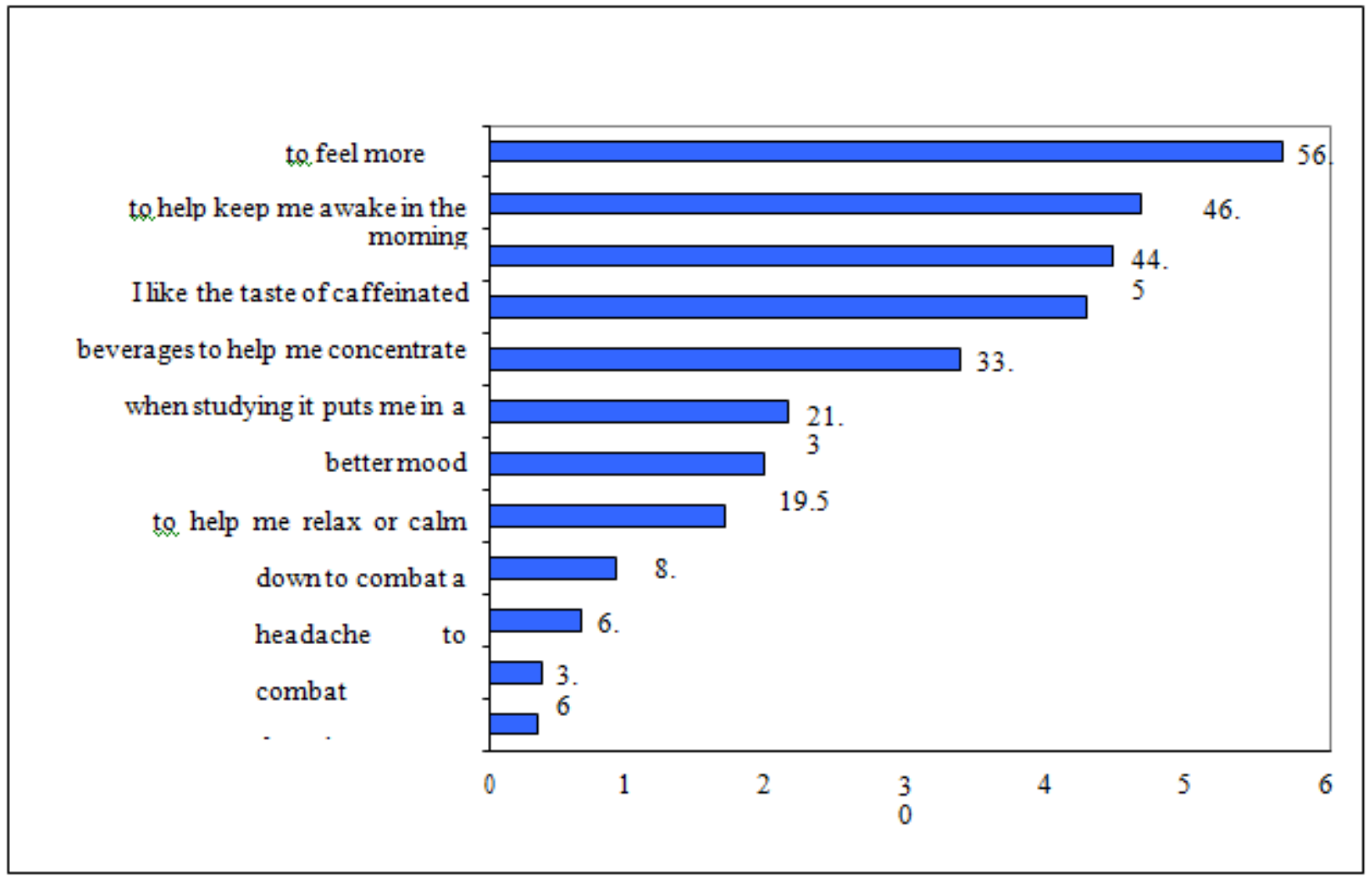

Figure 1: Reasons for caffeine consumption 


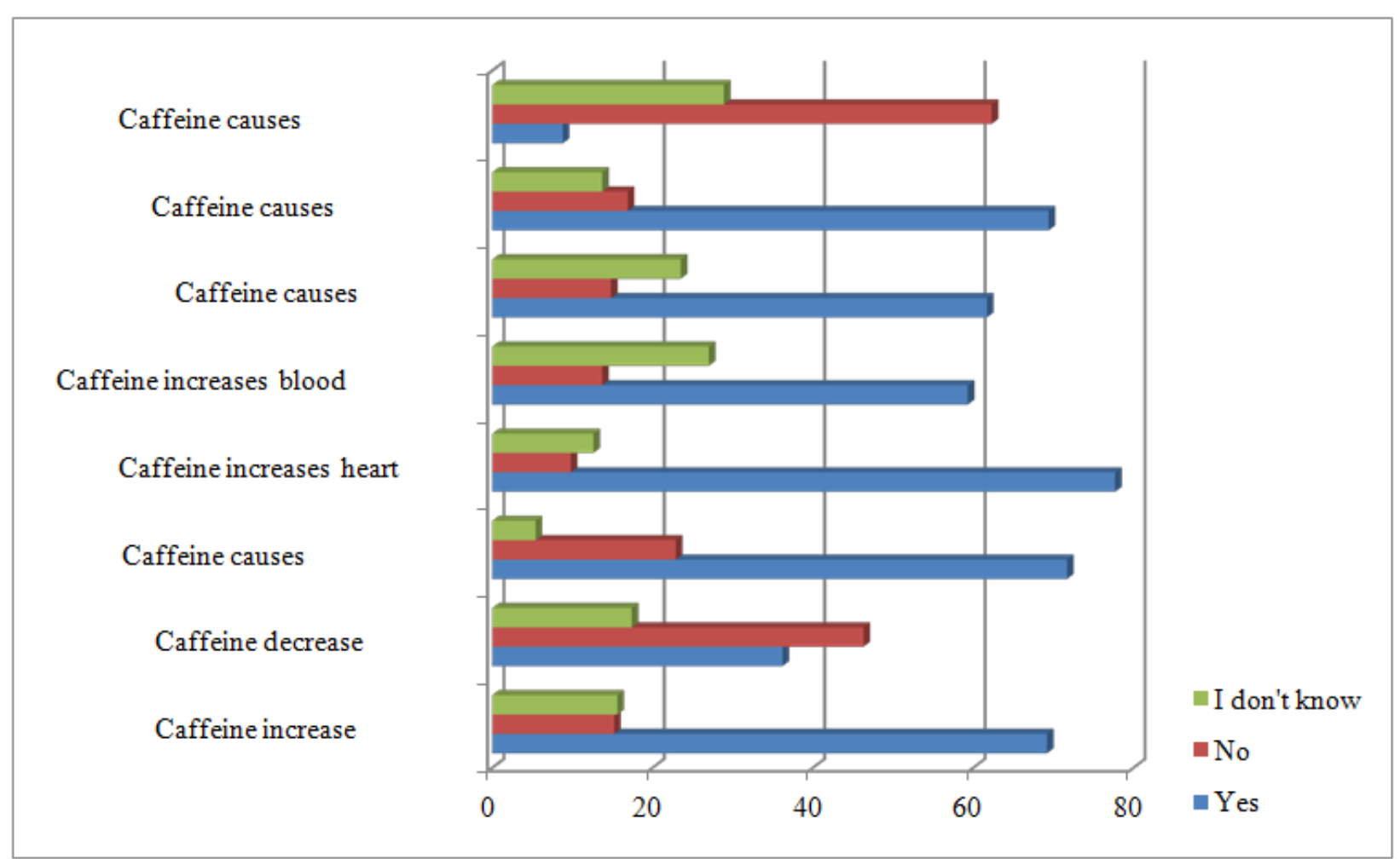

Figure 2: Awareness of caffeine effects 


\section{Appendix A}

Questionnaire

You are invited to participate in this study randomly. Completing this questionnaire will take maximally 5 minutes.

\section{DEMOGRAPHIC SECTION}

\section{Q1. Gender:}

1. Male

2. Female

Q2. Age: Q3. Academic year

$\begin{array}{ll}\text { 1. } & \text { First year } \\ \text { 2. } & \text { Second year } \\ \text { 3. } & \text { Third year } \\ \text { 4. } & \text { Fourth year } \\ \text { 5. } & \text { Fifth year }\end{array}$

\section{CAFFEINE CONSUMPTION HABIT SECTION}

Q4. Have you ever drunk any caffeinated beverage (coffee, soft drinks and energy drinks) in your life?

1. Yes

2. No

If you answered NO to Q4, please answer Q5 and go to awareness section, but if you answered YES, please skip Q5 and continue from Q6.

Q5. What is your reason for not consuming caffeine?

1. It is expensive

2. I don't like its taste

3. It is harmful to my health

4. Other

Q6. How often do you consume caffeine?

$\begin{array}{ll}\text { 1. } & \text { Daily } \\ 2 . & \text { Every week } \\ 3 . & \text { Every } 2 \text { weeks } \\ \text { 4. } & \text { Every } 3 \text { weeks } \\ \text { 5. } & \text { Every } 4 \text { weeks }\end{array}$




\section{International Journal of Science and Research (IJSR) ISSN (Online): 2319-7064 \\ Index Copernicus Value (2013): 6.14 | Impact Factor (2014): 5.611}

Q7. What is the average number of each drink you usually consume?

(Please, first check below the table to know the different size of cups then answer)

\begin{tabular}{|c|c|c|}
\hline \multicolumn{3}{|c|}{ Coffee } \\
\hline Type & Size & $\begin{array}{l}\text { Number of drinks } \\
\text { (circle the answer according to your answer to Q6) }\end{array}$ \\
\hline \multirow{4}{*}{ Black / Arabic coffee } & 8 ounces & $012345678910+$ \\
\hline & 12 ounces & $012345678910+$ \\
\hline & 16 ounces & $012345678910+$ \\
\hline & 20 ounces & $012345678910+$ \\
\hline \multirow{3}{*}{$\begin{array}{c}\text { Mocha Frappuccino/Coffee } \\
\text { Frappuccino' }\end{array}$} & 12 ounces & $012345678910+$ \\
\hline & 16 ounces & $012345678910+$ \\
\hline & 20 ounces & $012345678910+$ \\
\hline \multirow{4}{*}{ Caffe latte/Cappuccino } & 8 ounces & $012345678910+$ \\
\hline & 12 ounces & $012345678910+$ \\
\hline & 16 ounce & $012345678910+$ \\
\hline & 20 ounces & $012345678910+$ \\
\hline \multirow{3}{*}{ Iced coffee } & 12 ounces & $012345678910+$ \\
\hline & 16 ounces & $012345678910+$ \\
\hline & 20 ounces & $012345678910+$ \\
\hline \multirow{2}{*}{ Espresso } & Single shot & $012345678910+$ \\
\hline & Double shot & $012345678910+$ \\
\hline Ice Tea & 16 ounces & $012345678910+$ \\
\hline
\end{tabular}

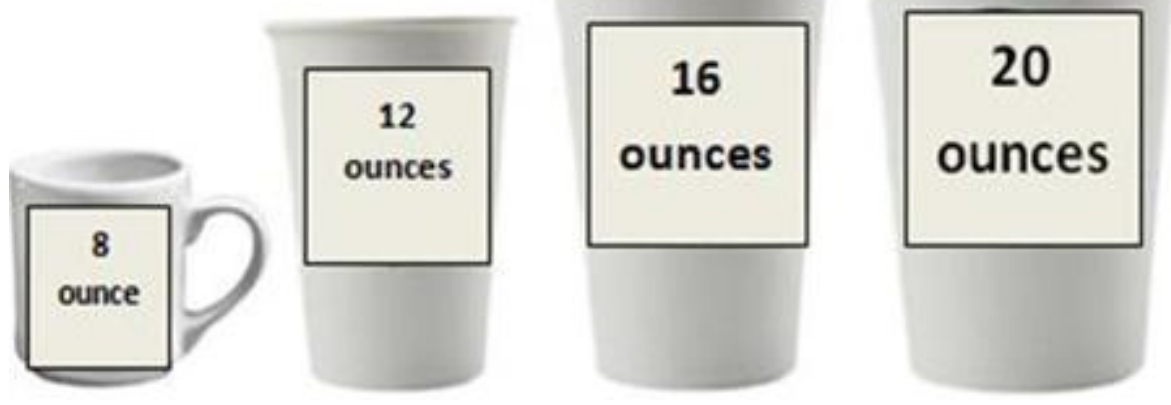

\begin{tabular}{|c|c|c|}
\hline \multicolumn{2}{|c|}{} & Soft drinks \\
\hline Type & Size & $\begin{array}{c}\text { Number of drinks } \\
\text { (circle the answer according to your answer to Q6) }\end{array}$ \\
\hline Pepsi & 12 ounces & $012345678910+$ \\
\hline Mountain Dew & 12 ounces & $012345678910+$ \\
\hline 7 -up & 12 ounces & $012345678910+$ \\
\hline Coca-Cola & 12 ounces & $012345678910+$ \\
\hline \multicolumn{2}{|c|}{ Energy drinks } \\
\hline Code Red & 12 ounces & $012345678910+$ \\
\hline Red bull & 8.3 ounces & $012345678910+$ \\
\hline
\end{tabular}

\section{Q8. I usually drink coffee:}

$\begin{array}{ll}\text { 1. } & \text { Morning } \\ \text { 2. } & \text { Pre-afternoon } \\ \text { 3. } & \text { After noon } \\ \text { 4. } & \text { Evening } \\ \text { 5. } & \text { never }\end{array}$


Q9. I usually drink soft drinks:

1. Before meals

2. With meals

3. After meals

4. Anytime during the day

5. Never

Q10. I usually drink energy drinks:

1. Before meals

2. With meals

3. After meals

4. Anytime during the day

5. never

Q11. Why do you consume caffeine? (You can choose more than one option)

1. To feel more alert.

2. To help keep me awake in the morning.

$3 . \quad$ To combat drowsiness.

4. To help me concentrate when studying.

5. To help deal with stress in my daily life.

$6 . \quad$ To help deal with depression.

7. To help me relax or calm down

8. To combat a headache.

9. It puts me in a better mood.

10. To help control my weight

11. I like the taste of caffeinated beverages.

12. Other

Q12. Do you consume caffeine "more than usual" during studying for exam?

1. Yes

2. No

\section{AWARENESS OF CAFFEINE EFFECTS SECTION}

Q13. Do you believe that caffeine consumption can increase arousal?

1. Yes

2. No

3. Don't know

Q14. Do you believe that caffeine consumption can decrease fatigue?

1. Yes

2. No

3. Don't know

Q15. Do you believe that caffeine consumption can cause restlessness (Lack of sleep)?

1. Yes

2. No

3. Don't know

Q16. Do you believe that caffeine consumption can increase heart rate?

1. Yes

2. No

3. Don't know 
Q17. Do you believe that caffeine consumption can increase blood pressure?

1. Yes

2. No

3. Don't know

Q18. Do you believe that caffeine consumption in high doses can cause anxiety?

1. Yes

2. No

3. Don't know

Q19. Do you believe that caffeine consumption in high dose for long time can cause addiction?

1. Yes

2. No

3. Don’t know

Q20. Do you believe that caffeine consumption in large dose for long time can cause hallucination?

1. Yes

2. No

3. Don't know

Q21. Have you ever tried to quit consuming caffeine products, but couldn't?

1. $\quad$ Yes

2. No

If you answered YES to Q21, please continue, but if you answered NO, please stop here and thank you.

Q22. Did you find it hard to concentrate because you couldn't consume caffeine?

1. Yes

2. No

Q23. Did you feel more irritable because you couldn't consume caffeine?

1. Yes

2. No

Q24. Did you feel nervous because you couldn't consume caffeine?

1. Yes

2. No

Q25. Did you feel anxious because you couldn't consume caffeine?

1. Yes

2. No

Q26. Did you feel a strong need or urge to consume caffeine?

1. Yes

2. No

Your participation is greatly appreciated. Thank you. 


\section{International Journal of Science and Research (IJSR) \\ ISSN (Online): 2319-7064}

Index Copernicus Value (2013): 6.14 | Impact Factor (2014): 5.611

\section{Appendix B}

\section{Consent form RESEARCH PROJECT TITLE}

Caffeine Habits among Medical Students in King Saud University

Principle investigator: Dr. Yousif Al-turki

Co-investigators: Basil Alenazy Abdulrhman Algadheeb Mazi Alanazi Abdulrahman Alanazi, Abdulsalam Almarzouqi Abdulelah Alanazi Mohammed Alanazi

Sponsor: King Saud University

You are being asked to participate voluntarily in a Research Study. If you decide to take part in this study, please sign this consent form and return it.

Study objective: To estimate the daily amount of caffeine consumption among medical students in college of medicine at King Saud University in Riyadh in 2012.

Benefits: The result of this study may not benefit you directly, but in the future, with Allah's will, the society will benefit from the knowledge acquired.

Side Effect: There are no side effects. You participation in this study does not have any further risks or discomfort to you.

Refusal: If you refuse to participate, there will be no penalty or loss of benefits.

Confidentality: Your participation in this study will be kept confidential. The results of this research may be published, however, your identity will never be revealed.

Approval: I fully understand the information and the consent form.

I sign freely and voluntarily. A copy has been given to me.

Investigator or Associate: Participant Name:

Signature: Signature:

Date: Date: 